\title{
The Importance of Single or Combined Use of Measurement Uncertainty and the Reference Change Value in the Diagnostic Evaluation of Biochemical Tests
}

\section{Biyokimyasal Testlerin Tanısal Değerlendirmesinde Ölçüm Belirsizliği ve Referans Değişim Değerinin Tek Başına veya Birlikte Kullanımının Önemi}

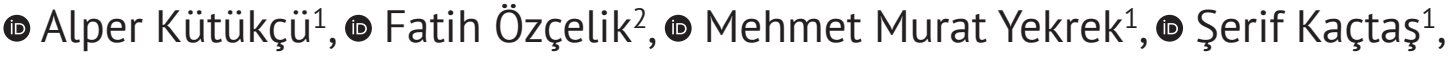 \\ ๑ Mehmet Zahit Çıracı ${ }^{3}$, ๑ Erdim Sertoğlu ${ }^{4}$, ๑ Halime Hanım Pençe ${ }^{3}$ \\ ${ }^{1}$ University of Health Sciences Turkey, Haydarpaşa Numune Training and Research Hospital, Clinic of Medical Biochemistry, Istanbul, Turkey \\ ${ }^{2}$ University of Health Sciences Turkey, Sultan 2. Abdülhamid Han Training and Research Hospital, Clinic of Medical Biochemistry, İstanbul, Turkey \\ ${ }^{3}$ University of Health Sciences Turkey, Hamidiye Faculty of Medicine, Department of Medical Biochemistry, Istanbul, Turkey \\ ${ }^{4}$ University of Health Sciences Turkey, Gülhane Faculty of Medicine, Department of Medical Biochemistry, Ankara, Turkey
}

Background: We aimed to improve the accuracy and reliability of our test results by calculating the measurement uncertainty (MU) and reference change value (RCV) for routine biochemical parameters.

Materials and Methods: For the MU estimation, 23 different routine biochemistry parameters were included in the study. For the RCV calculation of the tests, Fraser and logarithmic transformation formulas were used. The MUs were compared to the total allowable error recommendations defined by the CLIA and Westgard.

Results: When the estimated MU results of our laboratory were compared with the international limits, it was found that albumin, amylase, alanine transaminase, total bilirubin, direct bilirubin, blood urea nitrogen, calcium, creatinine kinase, chlorine, creatinine, glucose, potassium, lactate dehydrogenase, lipase, magnesium, sodium, total protein, phosphorus, C-reactive protein (CRP), aspartate transaminase, $\beta$-human chorionic gonadotropin, creatine kinase (CK)-MB (mass) and troponin-I test results were compatible with CLIA'88 limits, but the MU results of albumin, calcium, chlorine, magnesium, sodium and total protein were not compatible with Westgard limits. The RCV results, using Fraser approach, of CRP, CK, direct bilirubin, total bilirubin, lipase and troponin l-tests showed a wide range because of the high biological variations. The RCV's calculated limit value for CRP in the decreasing direction exceeded $100 \%$, which makes it impossible to use. However, when RCV was recalculated with logarithmic conversion formula, more usable results were obtained.

Conclusion: Each laboratory should calculate MU values to bring the reliability of test results close to international limits. Logarithmic transformation formulas should be used in the RCVs calculation of tests with high biological variation, such as CRP. In addition, MU and RCV should be given with the test results to improve diagnostic accuracy.

Keywords: Measurement uncertainty, reference change value, biological variation, logarithmic transformation

Amaç: Rutin biyokimyasal parametreler için ölçüm belirsizliğini (ÖB) ve referans değişim değerini (RDD) hesaplayarak test sonuçlarımızın doğruluğunu ve güvenilirliğini artırmayı amaçladık.

Gereç ve Yöntemler: ÖB tahmini için 23 farklı rutin biyokimya parametresi çalışmaya dahil edildi. Testlerin RDD hesaplaması için Fraser ve logaritmik dönüşüm formülleri kullanıldı. ÖB’leri, CLIA ve Westgard tarafından tanımlanan ve izin verilen toplam hata limitleriyle karşılaştırıldı.

Address for Correspondence: Fatih Özçelik, University of Health Sciences Turkey, Sultan 2. Abdülhamid Han Training and Research Hospital, Clinic of Medical Biochemistry, ìstanbul, Turkey

Phone: +90 5323279963 E-mail: 68ozcelik@gmail.com ORCID ID: orcid.org/0000-0003-2439-3964

Received: 23.07.2020 Accepted: 17.08.2020 
Bulgular: Laboratuvarımızda elde edilen ÖB sonuçları uluslararası limitlerle karşılaştırıldığında, albümin, amilaz, alanin aminotransferaz, total bilirubin, direkt bilirubin, kan üre azotu, kalsiyum, kreatinin kinaz, klor, kreatinin, glukoz, potasyum, laktat dehidrogenaz, lipaz, magnezyum, sodyum, total protein, fosfor, C-reaktif protein (CRP), alanin transaminaz, $\beta$-insan koryonik gonadotropini, kreatin kinaz (CK)-MB (mass) ve troponin-I testlerine ait ÖB sonuçlarının CLIA'88 limitlerini karşıladığı, ancak Westgard limitlerine göre albümin, kalsiyum, klor, magnezyum, sodyum ve total protein sonuçlarının başarısız olduğu saptandı. Biyolojik varyasyonlarının yüksekliği nedeni ile CRP, CK, direkt bilirubin, total bilirubin, lipaz ve troponin I-testlerinin klasik Fraser yaklaşımı ile hesaplanan RDD sonuçları, geniş aralık göstermekteydi. CRP için hesaplanan RDD’nin azalan yöndeki sınırı, kullanımı mümkün olmayacak şekilde yüzde 100 'ü aşmıştı. Oysa RDD, logaritmik dönüşüm formülü ile tekrar hesaplandığında daha kullanılabilir sonuçlara ulaşıldı.

Sonuç: Her laboratuvar, test sonuçlarının güvenilirliğini uluslararası sınırlara yakınlaştırmak için ÖB değerlerini hesaplamalıdır. CRP gibi biyolojik varyasyonu yüksek olan testlerin RDD hesaplamasında logaritmik dönüşüm formülleri kullanılmalıdır. Ayrıca, ÖB ve RDD’nin tanısal doğruluğunu artırmak için test sonuçları ile birlikte verilmelidir.

Anahtar Kelimeler: Ölçüm belirsizliği, referans değişim değeri, biyolojik varyasyon, logaritmik transformasyon

\section{Introduction}

Nowadays, more accurate, reliable and reproducible results can be achieved with quality improvement programs and improvements in clinical laboratories in order to be sufficiently beneficial to patients. However, despite all these improvements, results are not completely accurate or reliable. Medical decisions contain some margin of error since they are affected by laboratory results. Therefore, when reporting the result of a measurement, a numerical indicator (expressing the quality of the result) containing this doubt should be added. Without such an indication, the results could not be compared with each other or with the values given in the standards $(1,2)$. This can only be achieved by calculating the uncertainty of values obtained from the measurement and by reporting it with results.

The Guide to the expression of uncertainty in measurement (GUM) defines measurement uncertainty as "a parameter indicating the distribution of probabilities reported along with the measurement result and attributable to the measurement result". The International Vocabulary of Metrology - Basic and General Concepts and Associated Terms (VIM, item 2.26), on the other hand, defines it as a non-negative parameter that characterizes the distribution of values attributed to the measured (2). GUM and the Eurachem guideline adapted to the GUM in chemical measurements calculate uncertainty according to the bottom-up approach. This approach is based on identifying each potential source of uncertainty and calculating the individual uncertainty values for each component. The top-down approach is a method that uses existing laboratory test performance information (method validation, intra- and inter-laboratory CV data) (3).

The purpose of the measurement uncertainty is to help evaluating whether the result of one sample is significantly different from the other results. However, the uncertainty of measurement is not sufficient by oneself for the significance of the difference between the results obtained in successive measurements. To solve this issue, different parameters or concepts should be implemented $(4,5)$. One of the most applicable parameters is the reference exchange value (RCV), which tests the significance between two measurements by taking analytical and biological variations into account.

There are two components of biological variation, intraindividual and inter-individual. Intra-individual biological variation (CVI) is expressed as random fluctuations of components in the human body at the homeostatic set points. Random fluctuations, caused from individual changes, develop depending on the aging process, sex, weight, diet, exercise, hemostasis, daily or seasonal rhythms and, of course, pathological status and treatment. The variation in these differences is known as between-subject or inter-individual biological variation (CVG) $(4,6)$.

Medical laboratory results are compared with reference intervals for healthy individuals. However, a result within the reference interval does not guarantee that the result is normal for a specific patient. At this point, RCV, which includes biological variation and analytical variation, is used, which is a significant indicator of the change between the successive test results of the individual (5).

In this study, measurement uncertainty and RCVs of two different autoanalysers (Abbott Architect ci4100 and ci8200) were calculated in Medical Biochemistry Laboratory at University of Health Sciences Turkey, Haydarpaşa Numune Training and Research Hospital. Measurement uncertainty values were compared with the internationally accepted total allowable error limits to evaluate the quality of the results. Measurement uncertainty and the use of RCV together were also evaluated in the assessment of patient results. 


\section{Material and Methods}

Ethical approval for this retrospective study was obtained from the Ethics Committee of University of Health Sciences, Haydarpaşa Numune Training and Research Hospital (HNEAHKAEK 2017/KK/94). Informed consent from patients was not required. The Nordtest guide, "top-down" approach, was used to estimate measurement uncertainty. The calculations were performed using internal quality control (IQC) and external quality control (EQC) data.

\section{Statistical Analyses}

\section{IQC Data}

The original control sera supplied by Architect were studied 2 times a day (08 am and 06 pm) for all parameters to obtain IQC data (uncertainty-analytical process from reproducibility). Each lot has been evaluated and mean values, standard deviation (SD) and coefficient of variation (CV) values for each level were obtained.

\section{EQC Data}

EQC data of KBUDEK program were used for the bias calculation.

\section{Calculation of Measurement Uncertainty}

Measurement uncertainty calculation was completed in six stages as follows:

\section{Definition of measurement}

Measured parameter are; albumin, amylase, alanine transaminase (ALT), total bilirubin, direct bilirubin, blood urea nitrogen (BUN), $\mathrm{Ca}, \mathrm{Cl}$, creatinine, glucose, $\mathrm{K}, \mathrm{LDH}, \mathrm{CK}$, lipase, $\mathrm{Mg}, \mathrm{Na}$, total protein, $\mathrm{P}, \mathrm{C}$-reactive protein (CRP), aspartate transaminase (AST), $\beta$-human chorionic gonadotropin (HCG), creatine kinase (CK) -MB (mass) and troponin-I. Serum sample was used for all tests.

\section{Calculation of within-laboratory reproducibility (Rw) component of uncertainty}

Using the daily IQC data of each test, the mean, SD and CV values, respectively, were calculated as follows:

$$
\mathrm{SD}=\sqrt{\frac{\sum(\mathrm{xi}-\mathbf{x})^{2}}{\mathrm{n}-\mathbf{1}}}
$$

xi: measurement result, $\mathrm{x}$ : mean value, $\mathrm{n}$ : number of measurements

$\mathrm{CV} \%=100 * \mathrm{SD} / \mathrm{x}$

$\left.\left.\left.\mathbf{R w}=\sqrt{ }\left[\left(\mathrm{CV}_{1}\right)^{2}+\left(\mathrm{CV}_{2}\right)^{2}+\ldots .\right)_{\mathrm{LI}}+\left(\mathrm{CV}_{1}\right)^{2}+\left(\mathrm{CV}_{2}\right)^{2}+\ldots.\right)_{\mathrm{L} 2}+\left(\mathrm{CV}_{2}\right)^{2}+\ldots\right)_{L 3}\right] / \mathrm{n}$
CV1: CV\% during the period ( $\mathrm{n}$ times) used for lot 1, CV2: CV\% for lot 2

\section{L1: Low, L2: Normal and L3: High level, n: Total number of CV\%}

\section{Calculation of bias component of uncertainty:}

The bias can be obtained from certified reference material or EQC data. EQC data were used in this study.

Since it is recommended to use at least 6 attendance data over a given period of time (at least one year) to obtain reliable bias results from EQC data (7), 6 data were used (every 2 months) for CRP and 12 data for all other parameters (once a month).

$\mathrm{u}$ (bias) is divided into two as laboratory bias (RMSbias) and uncertainty component for the certified material [ $u(C r e f)]$.

The calculations were performed accordingly using the following formulas:

$$
\begin{aligned}
& \mathrm{u}(\text { bias })=\sqrt{\text { RMSbias }^{2}+\mathrm{u}(\text { Cref })^{2}} \\
& \text { RMS }_{\text {bias }}=\sqrt{\frac{\left.\sum \text { (bias }_{\mathrm{i}}\right) 2}{\mathrm{n}}}
\end{aligned}
$$

bias $_{i}$ : bias \% value of the test at that period, $n$ : the number of periods of participation in EQC

Calculation of the bias value of the laboratory from the EQC program;

bias $_{i}=100 \times\left|C l a b_{i}-C l a b_{\text {ref }}\right| / \mathrm{Clab}_{\text {ref }}$

$\mathrm{Clab}_{\mathrm{i}}$ : Laboratory measurement result, $\mathrm{Clab}_{\text {ref }}$ : Average measurement results of laboratories using the same method and device.

$\mathrm{u}(\mathrm{Cref})=\mathrm{CVR} / \sqrt{ } \mathrm{nLab}$

To calculate the CVR, CV\% values for all periods given in the EQC reports for the relevant test are summed and divided by the number of periods.

$n L a b$ : For each period of participation, the number of laboratories was summed, and the total number was divided by the number of periods.

\section{Conversion of components to standard uncertainty $u(R w)$}

The Rw values obtained in the second step were divided by 2 within the $95 \%$ confidence interval $(\mathrm{Cl})$ and the standard uncertainty value $u(R w)$ was obtained (8).

$u(R w)=R w / 2$

\section{Calculation of combined standard uncertainty, $\left(u_{c}\right)$}

$$
\mathrm{u}_{\mathrm{c}}=\sqrt{\mathrm{u}\left(\text { bias }^{2}+\mathrm{u}(\mathrm{Rw})^{2}\right.}
$$

\section{Calculation of expanded uncertainty (U) \\ $\mathrm{U}=\mathrm{k} \times \mathrm{u}_{\mathrm{c}} \quad \mathrm{k}=2$}


The k-value was taken as approximately 2, representing $95 \%$ $\mathrm{Cl}(9)$.

Rilibak limits were taken as the target value, since no limit value was specified for $\beta$-hCG in both guidelines. For $\beta$-HCG, Rilibak (Germany) has determined acceptable RMSD (\% root mean SD) as $14 \%$ (10).

An algorithm including all the above steps in the calculation of measurement uncertainty is presented in Figure 1.

\section{Calculations of Reference Change Value}

Tests for which RCV was determined; albumin, amylase, ALT, total bilirubin, direct bilirubin, $\mathrm{BUN}, \mathrm{Ca}, \mathrm{Cl}$, creatinine, glucose, $\mathrm{K}$, LDH, CK, lipase, Mg, Na total protein, P, CRP, AST, $\beta$-HCG, CK -MB (mass) and troponin-I.

In the calculation of RCV, analytical CV (CVA) values obtained using one-year IQC and intra-individual biological variation coefficient (CVI) were used. CVI values of serum samples for all tests were obtained from the Westgard website. RCV for $\beta$-HCG was not calculated because the CVI value was not available on the Westgard website. RCV calculation was performed using classical Fraser formula and logarithmic transformation formula. RCV (Fraser formula) $=Z \times 2^{1 / 2} \times C V T$

"Z"-value is 1.65 for one-way change in $95 \% \mathrm{Cl}$ while 1.96 for bidirectional change (11). In this study, the Z-value was assumed to be 1.65 , since the percentages of change in one direction were calculated.
The steps in the study of Lund et al. (12) were followed in the application of the logarithmic transformation formula to identify significant change in bidirectional.

\section{$\mathrm{CVT}=\sqrt{\mathrm{CVA}^{2}+\mathrm{CVI}^{2}}$}

Reference change factor up $\left(\mathrm{RCF}_{\mathrm{up}}\right)$ and reference change factor down ( $\mathrm{RCF}_{\text {down }}$ ) were obtained by using CVT and Z-values.

$\mathrm{RCF}_{\text {up }}=\exp (Z \times \sqrt{ } 2 \times \mathrm{CVT} / 100)$

$\mathrm{RCF}_{\text {down }}=1 / \mathrm{RCF}_{\text {up }}$

The patient's first test result was multiplied by the $\mathrm{RCF}_{\text {up }}$ value to determine the significant increase in consecutive test results of the patient. If the second test result was higher than this product result, this increase was considered significant. Likewise, the patient's first test result was multiplied by the $\mathrm{RCF}_{\text {down }}$ value. If the second test result was lower than the value obtained by this product result, this decrease was considered significant.

The individuality index (II) was used to determine the RCV value to be used to evaluate the significance of the change in successive test results as follows (13). CVI and CVG values were obtained from Westgard's website.

\section{II= CVI/CVG}

Microsoft office 2010 was used for statistical analysis and graphics design.

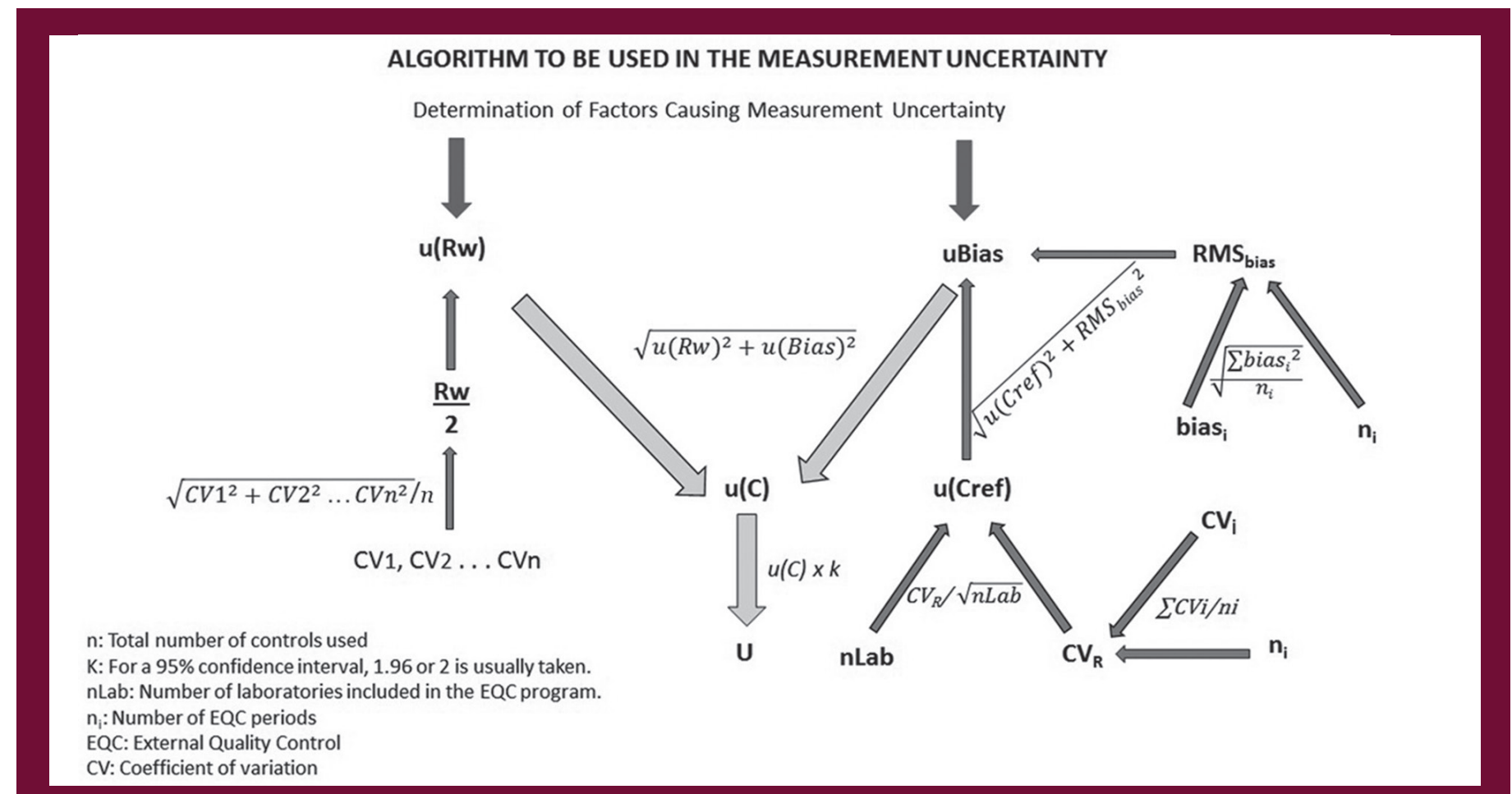

Figure 1. Algorithm to be used in measurement uncertainty 


\section{Results}

\section{- Results of Measurement Uncertainty}

When $\mathrm{U}$-values were examined, the results of the uncertainty obtained from all tests analyzed on our Architect ci4100 and ci8200 devices were within the CLIA'88 total error limits (Table 1, 2). However, it was observed that the uncertainty values determined for albumin, $\mathrm{Ca}, \mathrm{Cl}, \mathrm{Mg}, \mathrm{Na}$ and total protein analyzed on both devices did not reach the Westgard total error limits. The uncertainty value for $\beta$-HCG analyzed in the Ci8200 autoanalyser was $11.7 \%$. While this value was within the limits, the uncertainty value estimated in the ci4100 instrument was out of the limit (18.78\%).

\section{Results of RCV}

In the analysis based on the II of amylase, ALT, CK, creatinine, $\mathrm{LDH}, \mathrm{Mg}$, total protein, CRP, AST, CK-MB (mass), and troponin-I were $<0.6$ (Table 3). Accordingly, it was considered that the use of RCV in these tests was more appropriate. On the other hand, it was found that RCV could be used in addition to community-based reference intervals for albumin, total bilirubin, direct bilirubin, urea, calcium, chlorine, glucose, potassium, lipase, sodium and phosphorus with a high II $(\geqslant 0.6)$.

The RCV values obtained using both the Fraser method and the logarithmic transformation formula are as shown in Table 4 for all these tests. After applying the logarithmic transformation formula, one-way change values at $95 \% \mathrm{Cl}$ for each test were calculated separately as positive increase and negative decrease.

RCVs of total bilirubin, direct bilirubin, creatinine kinase, lipase and troponin-I tests calculated by logarithmic transformation were higher in increasing direction and lower in decreasing direction than the Fraser method. The RCV calculated according to the Fraser method exceeded $100 \%$ in decreasing direction, whereas the RCV calculated using logarithmic transformation was below $100 \%$ for CRP parameter (Figure 2).

\section{Discussion}

The appropriate application of modern medicine is unlikely without test results which are performed in clinical laboratories. In laboratory, the measurement of these tests is carried out by a series of complex precision instruments and various automated electronic equipment using test procedures. However, no test result is completely certain. These errors and uncertainties in test results may also vary depending on the measurement system, measurement procedure, operator skill, environmental situations and other influencers. Due to this distribution, the concept of uncertainty of measurements was needed to express the uncertainty in numbers $(1,14,15)$. In brief, the measurement uncertainty is the doubt that exists about any measurement results.

The basic assumption in calculating measurement uncertainty is based on providing information for the identification and correction of all systematic errors at early stage of the assessment process. The quality of a measurement is linked to the fact that uncertainty about random and systematic error (bias) is taken into account on the correct basis (16). It therefore includes all factors that affect the interpretation of the value used for diagnosis, treatment, and monitoring of patients. Furthermore, understanding the analytical aspects of the test for each laboratory is possible by defining the measurement uncertainty, which helps in the implementation of good clinical practice and reduces errors (17). Otherwise,

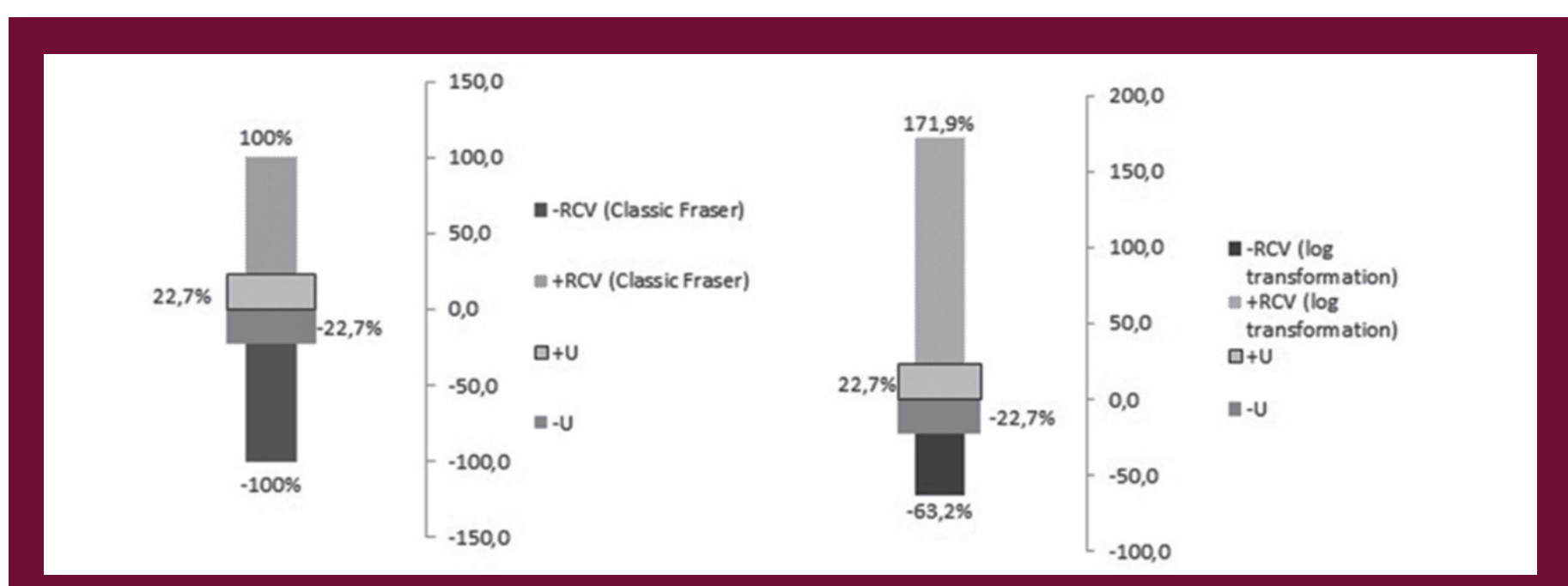

Figure 2. Measurement uncertainty $(U)$ and reference change value (RCV) calculated for CRP. A) RCV by Classical Fraser and $U$, B) RCV by logarithmic transformation and $\mathrm{U}$ 
these errors may increase medical costs and cause patients to be misdiagnosed, and even put patients in dangerous situations. Therefore, although measurement uncertainty is relatively new for clinical laboratories, it is an important issue (18). The measurement uncertainty is the datum that ensures the reliability of the result.

Two main approaches are recommended by international guidelines for calculating uncertainty. The bottom-up approach involves a comprehensive examination of measurements. In this approach, each source of uncertainty is determined one by one and the combined uncertainty value is obtained (3). The top-down approach is generally based on the evaluation of EQC data with IQC data. In studies conducted on the calculation of measurement uncertainty of some tests, it has been concluded that the results of measurement uncertainty obtained using both approaches are equivalent and can be used interchangeably (19).

The measurement uncertainty in clinical laboratories according to the down-to-up approach is difficult and time consuming. However, the up to down approach is based on bias and intra-laboratory reproducibility values. For this reason, clinical laboratories prefer this method, which is more simple in applicability, to calculate measurement uncertainty. Moreover, if the analytical conditions for total imprecision are met, the uncertainty components do not need to be identified and estimated separately unless there is a specific clinical objective. In addition, since the effects of uncertainty sources such as calibrator and reagent changes, technician change, humidity and temperature fluctuations are reflected to the IQC data in the long term, the top-down approach for determining the measurement uncertainty seems more useful for the laboratory $(20,21)$. For these reasons, we used the 6-step Nordtest guide with top-down approach to calculate measurement uncertainty in this study. Adhering to these principles, the $U$ values calculated from all the tests analyzed on our Architect ci4100 and ci8200 devices were within CLIA'88 total error limits, indicating that these values could be used for our laboratory. However, the $U$ values calculated for albumin, $\mathrm{Ca}, \mathrm{Cl}, \mathrm{Mg}, \mathrm{Na}$ and total protein were outside the Westgard limits. This finding suggested that improvements

Table 1. Uncertainty components, combined uncertainty and uncertainty of the expanded measurement of tests measured in the ci4100 instrument

\begin{tabular}{|c|c|c|c|c|c|c|c|c|}
\hline Test & RMS Bias & U (Cref) & uBias & $\mathrm{U}(\mathrm{Rw})$ & $u_{c}$ & U (\%) & Westgard TEa \% & CLIA88 TEa \% \\
\hline ALB & 4.34 & 0.49 & 4.36 & 1.83 & 4.73 & 9.46 & 4.07 & 10 \\
\hline ALT & 1.37 & 0.51 & 1.46 & 1.93 & 2.42 & 4.84 & 27.48 & 20 \\
\hline AMY & 5.25 & 0.42 & 5.27 & 1.19 & 5.40 & 10.80 & 14.6 & 30 \\
\hline AST & 1.60 & 0.37 & 1.64 & 1.16 & 2.01 & 4.01 & 16.69 & 20 \\
\hline D.BIL & 4.19 & 0.64 & 4.24 & 3.11 & 5.25 & 10.51 & 44.5 & - \\
\hline T.BIL & 4.31 & 0.74 & 4.37 & 2.25 & 4.92 & 9.84 & 26.94 & 20 \\
\hline BUN & 1.27 & 0.38 & 1.32 & 1.87 & 2.29 & 4.57 & 15.55 & 9 \\
\hline $\mathrm{Ca}$ & 1.84 & 0.30 & 1.86 & 1.45 & 2.36 & 4.73 & 2.55 & $10( \pm 1.0 \mathrm{mg} / \mathrm{dL})$ \\
\hline CK & 3.48 & 0.51 & 3.52 & 1.17 & 3.71 & 7.42 & 30.3 & 30 \\
\hline $\mathrm{Cl}$ & 1.03 & 0.22 & 1.05 & 0.75 & 1.29 & 2.57 & 1.5 & 5 \\
\hline CREA & 1.88 & 0.34 & 1.92 & 1.29 & 2.31 & 4.62 & 8.87 & 15 \\
\hline GLU & 2.39 & 0.33 & 2.41 & 1.20 & 2.70 & 5.39 & 6.96 & 10 \\
\hline K & 1.01 & 0.25 & 1.04 & 0.75 & 1.28 & 2.56 & 5.61 & $12.5( \pm 0.5 \mathrm{mmol} / \mathrm{L})$ \\
\hline LDH & 2.72 & 0.46 & 2.76 & 1.29 & 3.05 & 6.10 & 11.4 & 20 \\
\hline Lipase & 7.02 & 1.14 & 7.11 & 3.17 & 7.79 & 15.57 & 37.88 & - \\
\hline $\mathrm{Mg}$ & 2.87 & 0.73 & 2.96 & 1.70 & 3.41 & 6.82 & 4.8 & - \\
\hline $\mathrm{Na}$ & 0.88 & 0.19 & 0.90 & 0.62 & 1.09 & 2.18 & 0.73 & 2.85 ( $\pm 4 \mathrm{mmol} / \mathrm{L})$ \\
\hline$P$ & 1.33 & 0.37 & 1.38 & 1.68 & 2.17 & 4.35 & 10.11 & - \\
\hline TP & 2.74 & 0.35 & 2.76 & 1.37 & 3.08 & 6.17 & 3.63 & 10 \\
\hline CRP & 3.72 & 1.71 & 4.10 & 3.51 & 5.39 & 10.79 & 56.6 & - \\
\hline$\beta$-HCG & 8.73 & 0.78 & 8.77 & 3.35 & 9.39 & 18.78 & - & - \\
\hline CK-MB & 8.26 & 1.94 & 8.49 & 3.78 & 9.29 & 18.58 & 30.06 & - \\
\hline Tp-I & 4.96 & 1.62 & 5.21 & 3.49 & 6.27 & 12.55 & 27.91 & - \\
\hline
\end{tabular}


should be made to reduce the sources of error for these tests. For albumin test, $U$ values in Architect ci8200 instruments were found as $5.98 \%$. This value was consistent with the study performed by Bal et al. (18) on three different devices for albumin ( $U=7.35 \%, 6.49 \%$ and $6.47 \%$, respectively). However, this value was higher than the $U$ value $(3.4 \%)$ determined by lqbal et al. (22) for albumin. The $U$ values (9.46\%) determined for the albumin test in Architect ci4100 device were well above these data of two researches.

When some of the results obtained in our study were compared with previous studies, it was observed that $U$ values $(4.73 \%$ and $5.25 \%$ ) found in Architect ci4100 and ci8200 devices for Ca test were much higher than those found for plasma samples $(0.12 \%)$ by Padoan et al. (23) However, it was found that $U$ values (2.57\% and $2.86 \%$ ) found in Architect ci4100 and ci8200 devices for $\mathrm{Cl}$ test were lower than those determined by Padoan et al. (23) (3.76\%). For the Mg test, $U$ values (6.82\% and $11.36 \%$ ) found in Architect ci4100 and ci8200 devices were higher than those determined by lqbal et al. (22) (4\%) for their devices. The $U$ values for the Na test in Architect ci4100 and ci 8200 devices were $2.18 \%$ and $2.66 \%$ respectively, while
Bal et al. (18) found that $U$ values for the same analyte were close to our values as $2.32 \%, 2.21 \%$ and $2.07 \%$, respectively. Padoan et al. (23) found that $U$ value for $\mathrm{Na}$ was $1.81 \%$. For the total protein test, the $U$ values of Architect ci4100 and ci8200 devices were $6.17 \%$ and $5.39 \%$, respectively, whereas Bal et al. (18) obtained $U$ values for their 3 different devices as $8.40,8.51 \%$ and $8.39 \%$ respectively. Iqbal et al. (22) found the uncertainty value of $4.7 \%$ for total protein. According to all the above data, we had better performance compared to Bal et al. (18), worse than lqbal et al. (22) and different analyte-based performances with Padoan et al. (23).

When we examine our uncertainty results in detail, a bias error usually has a greater share. As a laboratory, we make our accuracy according to our results in the EQC program. However, the concentration of the analyte in the EQC sample is not given. Instead, the average of the measurement results of all laboratories participating in the EQC program is considered the real value. Therefore, this value also includes the errors of each laboratory from the analytical process during the measurement. As the number of laboratories participating in the EQC program increase,

Table 2. Uncertainty components, combined uncertainty and uncertainty of the expanded measurement of tests measured in the ci8200 instrument

\begin{tabular}{|c|c|c|c|c|c|c|c|c|}
\hline Test & RMS Bias & U (Cref) & U bias & $\mathrm{U}(\mathrm{Rw})$ & $u_{c}$ & U (\%) & Westgard TEa\% & CLIA88 TEa\% \\
\hline ALB & 2.29 & 0.49 & 2.34 & 1.86 & 2.99 & 5.98 & 4.07 & 10 \\
\hline ALT & 2.46 & 0.51 & 2.51 & 1.73 & 3.05 & 6.10 & 27.48 & 20 \\
\hline AMY & 4.34 & 0.42 & 4.36 & 1.41 & 4.58 & 9.16 & 14.6 & 30 \\
\hline AST & 2.21 & 0.37 & 2.24 & 1.42 & 2.65 & 5.30 & 16.69 & 20 \\
\hline D.BIL & 2.90 & 0.64 & 2.97 & 3.16 & 4.34 & 8.68 & 44.5 & - \\
\hline T.BIL & 4.65 & 0.72 & 4.71 & 2.96 & 5.56 & 11.12 & 26.94 & 20 \\
\hline BUN & 2.05 & 0.37 & 2.09 & 2.75 & 3.45 & 6.90 & 15.55 & 9 \\
\hline $\mathrm{Ca}$ & 1.97 & 0.29 & 1.99 & 1.71 & 2.62 & 5.25 & 2.55 & 10 ( $\pm 1.0 \mathrm{mg} / \mathrm{dL})$ \\
\hline CK & 2.96 & 0.51 & 3.00 & 1.52 & 3.37 & 6.74 & 30.3 & 30 \\
\hline $\mathrm{Cl}$ & 1.19 & 0.22 & 1.21 & 0.76 & 1.43 & 2.86 & 1.5 & 5 \\
\hline CREA & 2.08 & 0.34 & 2.10 & 1.63 & 2.66 & 5.32 & 8.87 & 15 \\
\hline GLU & 1.71 & 0.33 & 1.74 & 1.26 & 2.15 & 4.30 & 6.96 & 10 \\
\hline $\mathrm{K}$ & 1.03 & 0.25 & 1.06 & 0.78 & 1.32 & 2.64 & 5.61 & $12.5( \pm 0.5 \mathrm{mmol} / \mathrm{L})$ \\
\hline LDH & 4.34 & 0.45 & 4.36 & 1.90 & 4.76 & 9.51 & 11.4 & 20 \\
\hline Lipase & 6.30 & 1.14 & 6.41 & 2.96 & 7.05 & 14.11 & 37.88 & - \\
\hline $\mathrm{Mg}$ & 5.21 & 0.73 & 5.26 & 2.16 & 5.68 & 11.36 & 4.8 & - \\
\hline $\mathrm{Na}$ & 1.11 & 0.19 & 1.12 & 0.71 & 1.33 & 2.66 & 0.73 & $2.85( \pm 4 \mathrm{mmol} / \mathrm{L})$ \\
\hline $\mathrm{P}$ & 2.03 & 0.37 & 2.06 & 2.12 & 2.95 & 5.91 & 10.11 & - \\
\hline TP & 2.24 & 0.35 & 2.26 & 1.46 & 2.69 & 5.39 & 3.63 & 10 \\
\hline CRP & 10.43 & 1.71 & 10.57 & 4.10 & 11.34 & 22.68 & 56.6 & - \\
\hline$\beta$-HCG & 4.63 & 0.78 & 4.69 & 3.51 & 5.86 & 11.72 & - & - \\
\hline CK-MB & 4.88 & 1.94 & 5.25 & 3.34 & 6.23 & 12.45 & 30.06 & - \\
\hline Tp-I & 7.79 & 1.62 & 7.96 & 3.66 & 8.76 & 17.52 & 27.91 & - \\
\hline
\end{tabular}


the errors of the laboratories from this analytical process decrease to insignificant levels. Thus, it is accepted that the measurement results of the laboratories participating in the EQC program are remarkably close to the actual value. It is not recommended to use imprecision to estimate the measurement uncertainty resulting from the performance of laboratories in the EQC program when participation in the EQC program is low because there is generally less data for estimating uncertainty (20).

Another important factor affecting the EQC results and therefore the size of the bias result is that the samples are in lyophilized state (24). Therefore, the bias values of all tests belonging to the period in which the pipetting error during the reconstitution phase has been made will tend to come up high. The suggestion of glass pipettes in the reconstitution of such samples reduces the pipetting error but does not completely eliminate it. The best way to minimize bias resulting from the reconstitution of lyophilized samples is to use liquid samples instead of lyophilized samples for EQC, or

\begin{tabular}{|c|c|c|c|c|c|}
\hline Test & CVI & CVG & II & CVA & CVT \\
\hline ALB & 3.20 & 4.75 & 0.67 & 3.72 & 4.906 \\
\hline AMY & 8.7 & 28.3 & 0.31 & 2.80 & 9.140 \\
\hline ALT & 19.4 & 41.6 & 0.47 & 3.47 & 19.707 \\
\hline T.BIL & 21.8 & 28.4 & 0.77 & 5.72 & 22.538 \\
\hline D.BIL & 36.8 & 43.2 & 0.85 & 6.33 & 37.341 \\
\hline UREA & 12.1 & 18.7 & 0.65 & 4.92 & 13.062 \\
\hline $\mathrm{Ca}$ & 2.1 & 2.5 & 0.84 & 3.42 & 4.017 \\
\hline CK & 22.8 & 40 & 0.57 & 3.05 & 23.003 \\
\hline $\mathrm{Cl}$ & 1.2 & 1.5 & 0.80 & 1.52 & 1.940 \\
\hline CREA & 5.95 & 14.7 & 0.40 & 3.26 & 6.782 \\
\hline GLU & 5.6 & 7.5 & 0.75 & 2.52 & 6.142 \\
\hline $\mathrm{K}$ & 4.6 & 5.6 & 0.82 & 1.56 & 4.858 \\
\hline LDH & 8.6 & 14.7 & 0.59 & 3.80 & 9.401 \\
\hline Lipase & 32.2 & 31.8 & 1.01 & 5.92 & 32.740 \\
\hline $\mathrm{Mg}$ & 3.6 & 6.4 & 0.56 & 4.32 & 5.623 \\
\hline $\mathrm{Na}$ & 0.6 & 0.7 & 0.86 & 1.41 & 1.534 \\
\hline TP & 2.75 & 4.7 & 0.59 & 2.92 & 4.010 \\
\hline $\mathrm{P}$ & 8.15 & 10.8 & 0.75 & 4.23 & 9.185 \\
\hline CRP & 42.2 & 76.3 & 0.55 & 8.19 & 42.988 \\
\hline AST & 12.3 & 23.1 & 0.53 & 2.85 & 12.626 \\
\hline CK-MB (mass) & 18.4 & 61.2 & 0.30 & 7.13 & 19.732 \\
\hline$T p-I$ & 14.05 & 63.75 & 0.22 & 7.31 & 15.840 \\
\hline
\end{tabular}

II: Individuality index. If $\mathrm{II}<0.6, \mathrm{RCV}$ is used. If II $>1.4$, the reference interval is used. If $0.6<\|<1.4$, both are recommended to be used together. CVI: Intraindividual biologic variation, CVG: Inter-individual biologic variation, CVT: Total CV value, ALT: Alanine transaminase, AST: Aspartate transaminase, CI: Confidence interval, LDH: Lactate dehydrogenase, CRP: C-reactive protein, CK: Creatine kinase to use standard dilution samples with lyophilized samples. In the light of this information, we think that our $U$ values may be higher depending on the lyophilized EQC samples.

In the evaluation of the test results of individuals, reference intervals which are determined by age, gender and other variables that are not very compatible for themselves are used. This allows data to be used only in a superficial manner. However, it does not consider the basic information about reference intervals and the individual and inter-individual factors of the analytes. Therefore, it is controversial to evaluate the individual successive test results according to populationbased reference intervals $(25,26)$. Because, although there is no change (improvement or deterioration) in patients' current health status, one of the patients' consecutive results may be within the reference interval and the other may be out of the reference interval.

The reason for the changes observed in a person's successive test results may be due to the improvement of his clinical condition or vice versa, and was mostly attributed to CVI and CVA variables

Table 4. RCV values calculated by applying classical fraser and logarithmic transformation

\begin{tabular}{|l|l|l|l|}
\hline Test & $\begin{array}{l}\text { Class fraser } \\
\text { RCV (\%) }\end{array}$ & $\begin{array}{l}\text { Log. trans (\%) } \\
(+)\end{array}$ & $\begin{array}{l}\text { Log. trans (\%) } \\
(-)\end{array}$ \\
\hline ALB & 11.45 & 12.09 & -10.79 \\
\hline AMY & 21.33 & 23.69 & -19.16 \\
\hline ALT & 45.99 & 58.17 & -36.78 \\
\hline T.BIL & 52.59 & 68.94 & -40.81 \\
\hline D.BIL & 87.13 & 138.39 & -58.05 \\
\hline UREA & 30.48 & 35.51 & -26.21 \\
\hline Ca & 9.37 & 9.80 & -8.92 \\
\hline CK & 53.68 & 70.77 & -41.44 \\
\hline Cl & 4.53 & 4.62 & -4.41 \\
\hline CREA & 15.83 & 17.09 & -14.60 \\
\hline GLU & 14.33 & 15.36 & -13.31 \\
\hline K & 11.34 & 11.97 & -10.69 \\
\hline LDH & 21.94 & 24.45 & -19.65 \\
\hline Lipase & 76.40 & 114.19 & -53.31 \\
\hline Mg & 13.12 & 13.97 & -12.26 \\
\hline Na & 3.58 & 3.63 & -3.51 \\
\hline TP & 9.36 & 9.78 & -8.91 \\
\hline P & 21.43 & 23.82 & -19.24 \\
\hline CRP & 100.31 & 171.86 & -63.22 \\
\hline AST & 29.46 & 34.14 & -25.45 \\
\hline CK-MB (mass) & 46.04 & 58.26 & -36.81 \\
\hline TROP-I & 36.96 & 44.56 & -30.82 \\
\hline $\begin{array}{l}\text { The RCV was calculated as a one-way change in the } 95 \% \text { confidence interval. } \\
\text { ALT: Alanine transaminase, AST: Aspartate transaminase, Cl: Confidence } \\
\text { interval, LDH: Lactate } \\
\text { kinase }\end{array}$ & & & \\
\hline & & & \\
\hline & & & \\
\hline
\end{tabular}


(27). RCV can be detected using these variables. Although twoway change is generally used in RCV calculations, according to Cooper et al. (28), one-way change is more appropriate. Fraser also made similar recommendations when evaluating sequential troponin measurements in the assessment of acute cardiac cases (28). Therefore, we made our calculation based on one-way change. Since the analytical $\mathrm{CV}$ values of almost all tests on the Architect ci8200 device are higher than on the Architect ci4100, the CVA values of our Architect ci8200 device, which represent a wider range in RCV calculations, were based on.

The II determines whether the reference interval or RCV is preferred for the evaluation of individual test results. The use of population-based reference interval is not considered appropriate when the II is less than 0.6 because this reference interval will cover a very few individuals and will provide very limited benefit in assessing whether there is a significant change in results (29). Therefore, it would be more appropriate to compare the results with the previous basal results. For tests with an II greater than 1.4, reference interval should be preferred. It is reported that RCVs as well as reference intervals are more suitable for the evaluation of tests with an II less than 1.4 (4).

In a study conducted by Ko et al. (30), they calculated the RCV values as bidirectional at $95 \% \mathrm{Cl}$ according to the classical Fraser method. RCV values were found to be $9.47 \%$ for albumin, $5 \%$ for ALT, $24.2 \%$ for amylase, 34.4\% for AST, 33.7\% for BUN, $6.7 \%$ for calcium, $4.3 \%$ for $\mathrm{Cl}, 18 \%$ for creatinine, $102.1 \%$ for direct bilirubin, $15.8 \%$ for glucose, $12.9 \%$ for K, $24 \%$ for LDH, 3.2\% for $\mathrm{Na}, 7.9 \%$ for total protein, $22.7 \%$ for $\mathrm{P}$, and $60.5 \%$ for total bilirubin; respectively (30). These values were close to almost all our values except direct bilirubin. The decreasing RCV value determined by Ko et al. (30) for bilirubin was unusable because it exceeded $100 \%$. However, in our study, we found that the RCV value for the direct bilirubin in the decreasing direction with the classical Fraser approach was less than $100 \%$ and the RCV value calculated with the logarithmic transformation approach was $-58.05 \%$. As can be seen from this, it is not possible to use the Fraser approach in the decreasing direction, while the clinical use of the value determined by the logarithmic transformation approach is possible.

The RCV values obtained by Walz and Fierz by applying logarithmic transformation were close to the RCV values calculated in our study. There is a significant difference between only the RCV results of troponin-I test (140\% and - 58\%) (31). In our study, a narrower range was found for troponin-I test. This difference was probably attributable to the difference in analytical performance between laboratories and the type of sample used for troponin-I measurement. These researchers used plasma CVI values for troponin-I. Since the sample matrix, which is most suitable for analyzing, can be evaluated by the smallness of the CVI value, these researchers have obtained a larger RCV value, probably due to plasma use. However, we used serum samples in our study. In both studies, the reason for reaching similar results for many tests was attributed to the similar biological variation values as well as the close analytical performance of the instruments and kits.

Normally, the intra-individual biological variation shows a random fluctuation due to the homeostatic fluctuations of the individual (homeostatic set points). In addition, wider biological fluctuations will be observed in abnormal metabolic conditions such as disease, drug use, pregnancy and menopause. Therefore, in determining RCV values, it is considered that it is more appropriate to use the classical Fraser method for normal distribution tests and logarithmic transformation method for non-normal distribution tests. Furthermore, it is not possible to use RCV values calculated by the Fraser method above $100 \%$ in the direction of decrease, because such a reduction is not possible for repeated tests. In particular, it is considered that the logarithmic conversion formula should be preferred for tests that do not show normal distribution and have a wide biological variation (CRP, direct bilirubin, total bilirubin, troponin, creatinine kinase) $(4,6)$. In summary, since a significant proportion of individuals applying to hospitals consist of individuals with disease, drug use or abnormal metabolic conditions, laboratories should be able to calculate RCV values using both classical Fraser and logarithmic transformation and keep this information available.

\section{Conclusion}

Each laboratory should calculate MU values to bring the reliability of test results close to international limits. Logarithmic transformation formulas should be used in the RCVs calculation of tests with high biological variation, such as CRP. In addition, MU and RCV should be given with the test results to improve diagnostic accuracy.

\section{Ethics}

Ethics Committee Approval: Ethical approval for this retrospective study was obtained from the ethics committee of University of Health Sciences, Haydarpaşa Numune Training and Research Hospital (HNEAH-KAEK 2017/KK/94).

Informed Consent: Informed consent from patients was not required.

Peer-review: Externally and internally peer-reviewed.

\section{Authorship Contributions}

Project Development: F.Ö., A.K., M.M.Y., Data Collection or Processing: H.H.P., E.S., Ş.K., M.Z.Ç., A.K., M.M.Y., Analysis or Interpretation: F.Ö., Manuscript Editing: A.K., M.M.Y., H.H.P., E.S., Ş.K., M.Z.Ç., Writing: F.Ö. 
Conflict of Interest: No conflict of interest was declared by the authors.

Financial Disclosure: The authors declared that this study received no financial support.

\section{References}

1. Nellutla R, D RC. Point of view on measurement uncertainty in terms of quality management.J Med Sci Res. 2015;3:198-202. [Crossref]

2. JCGM. Evaluation of Measurement Data-Guide to the Expression of Uncertainty in Measurement Évaluation Des Données de Mesure-Guide Pour l'expression de l'incertitude de Mesure; 2008. www.bipm.org. Accessed October 24, 2019. [Link]

3. The Singapore Accreditation Council (SAC). Technical Guide 4 A Guide on Measurement Uncertainty in Medical Testing. Accreditation Scheme for Laboratories. SPRING Singapore; 2013. [Link]

4. Fraser CG, Harris EK. Generation and application of data on biological variation in clinical chemistry. Crit Rev Clin Lab Sci. 1989;27:409-437. [Link]

5. Regis M, Postma TA, van den Heuvel ER. A note on the calculation of reference change values for two consecutive normally distributed laboratory results. Chemom Intell Lab Syst. 2017;171:102-111. [Crossref]

6. Fraser CG. Change in serial results. In: Biological Variation: From Principles to Practice. Washington: AACC Press; 2001:67-90. [Link]

7. EUROLAB Tecnical Report No. 1/2007. Testing and Analytical Laboratories, Measurement Uncertainty Revisited - Alternative Approaches to Uncertainty Evaluation; 2007. https://www.eurolab.org/.Accessed October 24, 2019. [Link]

8. Magnusson B, Naykki T, Hovind H, Krysell M. Handbook for Calculation of Measurement Uncertainty in Environmental Laboratories. NT TR 537 Edition 3.1. Finland; 2012. www.nordtest.info. Accessed October 24, 2019. [Link]

9. American Association for Laboratory Accreditation.A2LA. G104 - Guide for Estimation of Measurement Uncertainty In Testing; 2014. http://anyflip. com/uazw/glrv/basic. Accessed October 24, 2019. [Link]

10. WESTGARDSQC. Rilibak - German Guidelines for Quality - Westgard. Tools, Technologies and Training for Healthcare Laboratories. https://www. westgard.com/rilibak.htm. Published 2015. Accessed October 24, 2019. [Link]

11. Cinpolat HY, Bugdayci G, Oguzman H, Yis MO. Calculation of Reference Change Values of Immun Analysis Parameters. Gazi Med J. 2015;26:85-87. [Crossref]

12. Lund F, Petersen PH, Fraser CG, Sölétormos G. Calculation of limits for significant unidirectional changes in two or more serial results of a biomarker based on a computer simulation model. Ann Clin Biochem. 2015;52(Pt 2):237-244. [Crossref]

13. Fraser CG. Inherent biological variation and reference values. Clin Chem Lab Med. 2004;42:758-764. [Crossref]

14. Bell S. A Beginner's Guide to Uncertainty of Measurement Measurement Good Practice Guide No. 11 (Issue 2); 1999. [Link]

15. Plebani M. Errors in clinical laboratories or errors in laboratory medicine? Clin Chem Lab Med. 2006;44:750-759. [Crossref]
16. Krouwer JS. Setting performance goals and evaluating total analytical error for diagnostic assays. Clin Chem. 2002;48(6 Pt 1):919-927. [Pubmed]

17. Milinković N, Ignjatović S, Šumarac Z, Majkić-Singh N. Uncertainty of Measurement in Laboratory Medicine. J Med Biochem. 2018;37:279-288. [Crossref]

18. Bal C, Serdar MA, Güngör OT, Çelik HT,Abuşoğlu S, Uğuz N, et al. Calculation of measurement uncertainty of biochemical parameters. Turkish J Biochem. 2014;39:538-543. [Crossref]

19. Lee JH, Choi J-H, Youn JS, Cha YJ, Song W, Park AJ. Comparison between bottom-up and top-down approaches in the estimation of measurement uncertainty. Clin Chem Lab Med. 2015;53:1025-1032. [Crossref]

20. White GH, Farrance I, AACB Uncertainty of Measurement Working Group. Uncertainty of measurement in quantitative medical testing: a laboratory implementation guide. Clin Biochem Rev. 2004;25:S1-24. [Pubmed]

21. Ellison Secretary US, Bettencourt da Silva R, Poland Fodor EP, et al. EURACHEM/CITAC Guide Quantifying Uncertainty in Analytical Measurement Composition of the Working Group* EURACHEM Members A Williams Chairman A Brzyski R Kaus E Amico Di Meane M Rösslein A Fajgelj IAEA Vienna; 2009. [Link]

22. Iqbal S, ljaz A, Sharafat S. Estimation of uncertainty measurement - A prerequisite of ISO1589 accreditation for clinical laboratories. J Pak Med Assoc. 2017;67:701-705. [Pubmed]

23. Padoan A, Antonelli G, Aita A, Sciacovelli L, Plebani M. An approach for estimating measurement uncertainty in medical laboratories using data from long-term quality control and external quality assessment schemes. Clin Chem Lab Med. 2017;55:1696-1701. [Crossref]

24. Elin RJ, Gray BA. Liquid and lyophilized quality-control materials compared for use in continuous-flow analysis. Clin Chem. 1984;30:129131. [Pubmed]

25. C28-A2. How to Define and Determine Reference Intervals in the Clinical Laboratory; Approved Guideline-Second Edition This Document Contains Guidelines for Determining Reference Values and Reference Intervals for Quantitative Clinical Laboratory Tests. A Guidelin. Vol 20; 2000. www.nccls. org. Accessed October 24, 2019. [Link]

26. Bourgès-Abella NH, Gury TD, Geffré A, Concordet D, Thibault-Duprey KC, Dacuhy $A$, et al. Reference intervals, intraindividual and interindividual variability, and reference change values for hematologic variables in laboratory beagles. J Am Assoc Lab Anim Sci. 2015;54(1):17-24. [Pubmed]

27. Fraser CG. Reference change values. Clin Chem Lab Med. 2012;50:807812. [Crossref]

28. Cooper G, DeJonge N, Ehrmeyer S, Yundt-Pacheco J, Jansen R, Ricos C, et al. Collective opinion paper on findings of the 2010 convocation of experts on laboratory quality. Clin Chem Lab Med. 2011;49:793-802. [Crossref]

29. Young DS. Preanalytical variables and biological variation. In: Burtis, Carl A. Ashwood, Edward R. Bruns, David E. Tietz Textbook of Clinical Chemistry and Molecular Diagnostics. Elsevier Health Sciences; 2012:2259. [Link]

30. Ko DH, Park HI, Hyun J, Kim HS, Park MJ, Shin DH. Utility of Reference Change Values for Delta Check Limits. Am J Clin Pathol. 2017;148:323329. [Crossref]

31. Walz B, Fierz W. Der Referenzbereich ist tot - es lebe der Reference Change Value. Ther Umsch. 2015;72:130-135. [Crossref] 